\title{
The breakdown of leaves of poplar and holm oak in three Moroccan streams : effect of burial in the sediment
}

\author{
B. Naamane ${ }^{1}$ \\ H. Chergui ${ }^{1}$ \\ E. Pattee ${ }^{2}$
}

Keywords : decomposition, poplar, holm oak, burial, watercourse.

Weight loss of leaves of Populus nigra and Quercus ilex was observed in coarse-mesh bags exposed in three watercourses and their sediment $(-30$ and $-50 \mathrm{~cm})$ near the city of Fes. The watercourses were: Oued Sebou (a river), Oued Sidi-Harazem (issuing from a warm spring), and Ain Chkef (a cold spring).

Weight loss was faster at the surface than within the sediment.

Weight loss was faster in poplar than in the tough holm oak leaves.

At all levels, weight loss was fastest in Oued Sebou where the water flowed faster both at the surface and within the coarser sediment. It was slowest in the cold spring.

Thus the influence of leaf texture, current velocity, and temperature were stressed.

Dégradation des feuilles de peuplier et de chêne vert dans trois cours d'eau marocains : effets de l'enfouissement dans les sédiments

Mots-clés : décomposition, peuplier, chêne-vert, enfouissement, cours d'eau.

La dégradation des feuilles de peuplier noir (Populus nigra) et de chêne vert (Quercus ilex) est suivie par la mesure de la perte de poids des feuilles dans des sacs à grandes mailles, enfouis ou non dans le sédiment de trois cours d'eau de la région de Fès : le Sebou (fleuve), le Sidi Harazem (ruisseau issu d'une source chaude) et Aïn Chkef (source froide).

Les effets de l'enfouissement sur la dégradation des feuilles dans les sédiments des cours d'eau sont déterminés en comparant les taux de dégradation à différentes profondeurs $(0,-30$ et $-50 \mathrm{~cm})$. Les résultats montrent que :

- Les feuilles incubées à la surface perdent plus rapidement leurs poids que celles enterrées.

- Le peuplier disparaît plus rapidement que le chêne vert.

- Pour les deux espèces, la dégradation la plus rapide est enregistrée dans l'oued Sebou et la plus lente dans l'oued d'Aïn Chkef. Ces différences semblent dues à l'agitation de l'eau en surface et à sa circulation dans les sédiments ainsi qu'à la température, deux facteurs connus pour favoriser l'action des microorganismes et des invertébrés.

\section{Introduction}

The breakdown of organic matter is the main process that allows the dissipation of energy and that makes the

1. Hydrobiologie et Écologie Générale, Faculté des Sciences Dhar el Mehraz, B.P. 1796, Fès-Atlas, Maroc.

E-mail<naamaneb@yahoo.com>

2. UMR CNRS Écologie des Hydrosystèmes Fluviaux, Université

Claude Bernard Lyon-I, 69622 Villeurbanne Cedex, France.

E-mail<pattee@biomserv.univ-lyon1.fr> nutrients stocked in biomass available to the ecosystem (Fisher \& Likens 1973, Cummins et al. 1973, Bärlocher \& Kendrick 1974, Pattee et al. 1986). Attempts have been made to distinguish the abiotic components of this process (leaching, physical breakdown) from the biotic components (the action of bacteria and fungi which transform plant organic matter into microbial biomass and the action of invertebrates who shred and eat coarse particulate detritus) (Kaushik \& Hynes 1971, Cummins et al. 1973). These processes are influenced by the physical and chemical characteristics of the environment such as temperature, current velocity, substratum grain size, oxygen, nitrogen, and 
phosphorus content of the water (Petersen \& Cummins 1974, Suberkropp et al. 1975, Chergui \& Pattee 1988, Boulton \& Foster 1998).

The sediment of watercourses is disturbed, continuously or at least each time there is a flood, and plant litter thus becomes buried. Underground ecosystems are known to depend upon trophic inputs from the surface (Cummins 1974, Leichtfried 1985, Gibert 1986), but the effect of the burial of particulate organic matter on its breakdown and on the distribution of the macrofauna have been less investigated (Herbst 1980, Rounick \& Winterbourn 1983, Mayack et al. 1989, Essafi et al. 1994, Boulton \& Foster 1998).

Holm oak (Quercus ilex) represents the climax in most Mediterranean landscapes and covers great areas in which it accumulates a specially tough litter on the ground. Except for the data of Gessner \& Chauvet (1994) who measured its breakdown in the water, we are only aware of terrestrial investigations (PoinsotBalaguer \& Livrelli 1994, Orgeas et al. 1998) on this litter.

The aim of the present work was to compare the effects of burial of two leaf species in the sediment of three Mediterranean watercourses on weight loss and possible breakdown by invertebrates.

\section{Material and methods}

\subsection{Collection of leaves}

Holm oak has tough evergreen leaves with a thick cuticle. For comparison we chose poplar (Populus nigra) which has broad and softer leaves whose breakdown has been formerly investigated.

The leaves were collected at the end of November 1995 by shaking the trees above a sheet. As the state in which most plant litter reaches the water in the semiarid Northeastern Moroccan climate is still uncertain (Chergui \& Pattee 1991b), the leaves were dried to constant weight at $40^{\circ} \mathrm{C}$ for $48 \mathrm{~h}$, then weighed to the nearest $0.2 \mathrm{mg}$ by batches of 2 or $3 \mathrm{~g}$ and enclosed in plastic bags until they were used.

\subsection{Study sites}

The investigations were performed in three Central Moroccan watercourses: Oued Sebou and Oued Sidi Harazem, both located in the Upper Sebou Basin on varied substratum but dominating limestone and marl, and Oued Ain Chkef located in the Saiss Plain on limestone bedrock between the Middle Atlas and the Rif foothills.

\section{The Sebou (site $\underline{\text { ) }}$}

The samples were collected from site $S$, immediately downstream from the Portuguese bridge on the road from Fes to Al-Hoceima. The substratum is cobble, sand and partly-emerging boulders. Depth varied between 15 and $75 \mathrm{~cm}$, width was approximately $20 \mathrm{~m}$ and maximum flow velocity close to $0.5 \mathrm{~m} . \mathrm{s}^{-1}$. Filamentous Ulvaceae algae grew in the water and the scanty riparian vegetation included Nerium oleander, Foeniculum, and thistle.

\section{Oued Sidi Harazem (site $\underline{\text { H) }}$}

This small tributary of Oued Sebou issues from the hot Sidi Harazem springs. Lower down it receives water from a cold extrusion and from a small tributary polluted by the village of Sidi Harazem. Self-purification operates along its course downhill but water is abstracted for irrigation. The samples were collected from site $\mathrm{H}$, immediately downstream from the FesTaza road. Here the bed is coarse gravel, cobble and stones. Depth was 7-15 cm, width $3 \mathrm{~m}$, and flow velocity about $0.25 \mathrm{~m} . \mathrm{s}^{-1}$. The dense riparian vegetation was mostly Arundo donax, Morus alba, Rubus, $\mathrm{Cu}$ pressus, Rhamnus, Nephnelepsis (Polypodiaceae) and Convolvulus.

\section{Oued Ain Chkef (site K)}

This extrusion flows out from the Saiss limestone $6 \mathrm{~km}$ to the south of Fes. A part of the water is used to fill an underground tank for the touristic complex of Ain Chkef. The remainder flows at site $\mathrm{K}$ over cobbles covered with organic sand and silt. Depth is close to $30 \mathrm{~cm}$, width to 5-6 m, and flow velocity never exceeds $0.20 \mathrm{~m} . \mathrm{s}^{-1}$. The site is overgrown with filamentous algae (Enteromorpha, Oscillatoria) and the emergent macrophytes Typha, Mentha and Helosciadium. Lavandula multifida, thistle, Carex, Acacia cyanophylla, Morus alba and Ficus carica grow along the banks. The vicinity is planted with Eucalyptus camaldulensis.

\subsection{Physics and chemistry of the water}

Samples were collected both from surface water and at $-50 \mathrm{~cm}$ within the sediment, from the bottom of the cylinders used for the artificial substrates (see hereafter) and that had been emptied of their sediment. Stoppered 500-ml flasks were introduced into the cylinders, filled with water and closed again before lifting them to the surface. Care was taken to cause as little bubbling as possible. Interstitial water for measuring dissolved oxygen concentration was collected by the Bou \& Rouch (1967) tubing method. The gear required was only available in Fes after the study period and samples were collected from November 1998 to March $1999(16 / 11,02 / 12,20 / 12,08 / 01,01 / 02,23 / 02$, and 
22/03). The water was pumped with a WAB peristaltic pump from a pipe sunk $50-\mathrm{cm}$ deep in the sediment. The water was poured into $250-\mathrm{ml}$ flasks that were immediately closed, taking care to limit contact with the atmosphere.

Conductivity, temperature, and $\mathrm{pH}$ were measured in the field, in flasks filled with water from the surface and from the bottom of the cylinders, with a conductithermometer and a pH-meter. In the laboratory, alkalinity was evaluated with hydrochloric acid and a coloured solution (bromocresol green and methyl red, Rodier 1975). Dissolved oxygen was measured by the Winkler Method (Rodier 1975), the first steps of the reaction in the field and the remainder in the laboratory.

\subsection{Grain size of the sediment}

Sediment was collected from three depths [0, $-10 \mathrm{~cm}],[-25,-35 \mathrm{~cm}]$ and $[-40,-50 \mathrm{~cm}]$ at each site. Grain size between 64 and $0.063 \mathrm{~mm}$ was measured by dry sieving. The mass of each size class was given as a percentage of total mass of the sample.

\subsection{Leaf breakdown}

The dry leaves were enclosed in $10 \times 10 \mathrm{~cm}$ plastic meshbags with $15 \times 21 \mathrm{~mm}$ coarse meshes. Such large meshes allow the access of all invertebrates to the leaves, and even of some fishes and tadpoles at the surface of the sediment. Thus it was intended to simulate natural breakdown. Each bag was identified by a small plastic label on which the exact dry weight of the leaves contained was written.

We exposed 756 bags ( 3 sites $x 2$ leaf species $x 3$ depths $x 7$ collection dates $x 6$ replications) at the end of March 1996. They were deposited in and above the artificial substrates as follows.

P.V.C. cylinders $50 \mathrm{~cm}$ high and with $11.5 \mathrm{~cm}$ inner diameter, pierced with $20-\mathrm{cm}$ diameter holes, were sunk into the sediment. They were not traps, as the water, fine sediment, organic matter, and animals could move in and out. All sediment contained was removed (this is when the samples of water were collected) and six litter bags were deposited at the bottom of the cylinder $(-50 \mathrm{~cm})$. Sediment collected from the site itself was added as far up as $-30 \mathrm{~cm}$, where six other bags were placed. Then the cylinder was filled up to the surface and six bags were placed upon the sediment and tied to the holes of the cylinder with a nylon thread.

The cylinders were set at least $1 \mathrm{~m}$ from each other, 14 of them in each station ( 7 for poplar and 7 for holm oak leaves). At each sampling date (after 15, 30, 45, $60,90,120$, and 150 days), the content of one cylinder of each leaf species ( 6 bags x 3 depths) was collected. The mesh bags were immediately inserted into waterproof plastic bags so as to avoid the loss of leaf material or animals.

In the laboratory, the following operations were performed:

- Each leaf or its remains were cleaned with a soft paintbrush under a small jet of water above a $200 \mu \mathrm{m}$ mesh sieve to eliminate fine detritus and silt. This operation requires much care and all the more so with the leaves that have remained longer in the water.

- Macrofauna was collected, fixed in formalin, classified according to trophic groups (Cummins \& Wilzbach 1985, Tachet et al. 1996), and enumerated.

- The leaves were dried at $40{ }^{\circ} \mathrm{C}$ for $48 \mathrm{~h}$ and weighed again to the closest $0.2 \mathrm{mg}$.

\subsection{Hyphomycetes}

The colonisation of naturally-fallen poplar leaves, both fresh and dried for $48 \mathrm{~h}$ at $40^{\circ} \mathrm{C}$, by hyphomycetes was investigated at the Ain Chkef site. Batches of four fresh or four dried leaves were enclosed in bags with $1 \mathrm{~mm}$ meshes and placed in the sediment of the site as explained above : one bag with fresh and one bag with dried leaves at $-50 \mathrm{~cm}$, then one of each category at $-30 \mathrm{~cm}$, and one of each category at the surface of the sediment. Nine substrates were placed at the site, each of them with six bags (fresh and dry $x 3$ depths), altogether 54 bags. These were collected between November 1996 and March 1997 (25/11, 10/12, 25/12, $13 / 01,28 / 01,13 / 02,27 / 02,15 / 03 ; 30 / 03$ ).

The occurrence of hyphomycetes was investigated by two methods : a more direct method and a method with longer incubation. In the first method, individual leaves were placed in vials with distilled sterilised water for $24 \mathrm{~h}$ at $10^{\circ} \mathrm{C}$. Then the surface of each leaf was scraped and the debris were mounted on a slide and examined under the microscope. In the second method, individual leaves were incubated in water from the Ain Chkef site that had been filtered on a cotton plug, sterilised, and that was continuously aerated by bubbling for one week at $10{ }^{\circ} \mathrm{C}$. Then leaf surfaces were scraped and the debris examined as above.

\subsection{Statistical methods}

Weight loss versus time was evaluated by the slope of the semi-log regression line (daily exponential breakdown coefficient k). ANOVA and ANCOVA were used for comparing breakdown between leaf species, and among sites and depths. 


\section{Results}

\subsection{Physical and chemical characteristics of the sites}

Variations versus time and space are shown in Fig. 1.

At the Sebou site, temperature followed seasonal fluctuations, it was slightly lower in spring and higher in summer. No variation appeared at the other two sites, but temperature was higher at Sidi Harazem than at Ain Chkef. In all three sites, no difference appeared between surface water and the water collected from the bottom of the cylinders.

In spring and especially on day 30 (the end of April), $\mathrm{pH}$ was generally lower than in summer and, in contrast with temperature, $\mathrm{pH}$ in the cylinders was often lower than in the river above.

Dissolved oxygen content (as measured late in the morning) increased much in summer and exceeded saturation by 112,106 , and $105 \%$ at the end of June, the end of July, and the beginning of September, respectively, in the Sebou, and by $108 \%$ at the beginning of September at Ain Chkef. Oxygen content in the interstitial water collected two years after the other investigations (Fig. 2) varied between de 0.2 and 1.9 mg.L ${ }^{-1}$ at $\mathrm{H}$ and $\mathrm{K}$. It was higher at $\mathrm{S}$, between 1.3 and 3.9 $\mathrm{mg} . \mathrm{L}^{-1}$ and surprisingly it varied in opposition with that of the other two sites.

Conductivity was high in the Sebou and Sidi Harazem (750-1160 and 800-1020 $\mu$ S.cm ${ }^{-1}$, respectively,

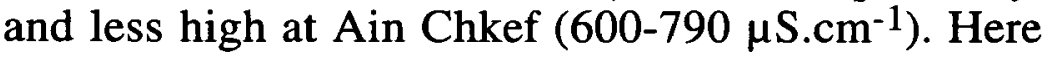
again, no difference appeared between the surface water and that in the cylinders.

Alkalinity is due to bicarbonates, carbonates, and hydroxides. Great variation appeared in the water from the cylinders at $\mathrm{H}$ and $\mathrm{K}$. The other values were close to $200-300 \mathrm{mg} . \mathrm{L}^{-1}$.

\subsection{The sediment (Fig. 3)}

Differences appeared among the sites, whereas at each of them, sediment composition seemed stable enough versus depth. Sand and silt dominated in Ain Chkef and Sidi Harazem. All strata had particles larger than $64 \mathrm{~mm}$ in the Sebou.

\subsection{Leaf breakdown}

\section{- Poplar (Fig. 4, Table 1)}

Weight loss proceeded exponentially with correlation coefficients of 0.97 in the Sebou, 0.87 at Sidi Harazem, and 0.98 at Ain Chkef.

At all three sites leaves lost weight faster when they were at the surface than when they were buried $50 \mathrm{~cm}$ in the sediment $(\mathrm{P}<0.05$, Table 2$)$. Breakdown rate was intermediate at $-30 \mathrm{~cm}$.

Whatever the depth in the sediment, leaves lost weight faster in the Sebou than at Ain Chkef $(\mathrm{P}<0.05$, Table 2). Breakdown rate was intermediate at Sidi Harazem.

After 150 days in Oued Sebou, only $3 \%$ of the dry weight of surface leaves remained and $22 \%$ of those at -30 and $-50 \mathrm{~cm}$. Respective values were 23,42 , and $52 \%$ at Ain Chkef. Breakdown rates at -30 and $-50 \mathrm{~cm}$ in the Sebou were identical, weights did not differ significantly on days $15,90,120$, and 150 .

\section{- Holm oak (Fig. 5, Table 1)}

Variation was lower than in poplar. Although the curves ranked in the same order as those of poplar, the effect of burial was less evident : no significant differences appeared between the curves at the three depths (Table 2), but most weight losses differed significantly after the 60th day (ANOVA, $\mathrm{P}<0.05$ ).

Despite the absence of significant differences among the curves of the three stations (Table 2), breakdown seemed slower in Ain Chkef (38\% after 150 days at the surface versus $47-49 \%$ in the other sites and the same differences among sites within the sediment) (ANOVA, $\mathrm{P}<0.05$ ).

Breakdown was always slower than that of poplar $(P<0.05$, Table 2). During the first two weeks (leaching included), weight loss of holm oak leaves was close to $20 \%$ and further weight loss was limited. At two weeks, it was close to $40 \%$ in poplar leaves.

\subsection{Invertebrate numbers during leaf breakdown}

The taxa collected in the three sites and their classification among trophic groups are given in Table 3. Fig. 6 shows the changes in invertebrate numbers per leaf weight remaining in each bag. Colonisation of poplar leaves increased gradually. Especially at the surface, invertebrate numbers were lower in holm oak leaves. In fact, after an initial increase, total invertebrate numbers generally levelled off or even decreased at the end of the experimental period. This decrease was particularly marked at site $\mathrm{K}$. Note that a decrease per remaining leaf weight means a still greater decrease per leaf bag.

In the deeper sediment layers, no correlation seems to have existed between invertebrate numbers and breakdown rate: occasionally invertebrates were numerous while breakdown was slow (as on poplar in site K). 

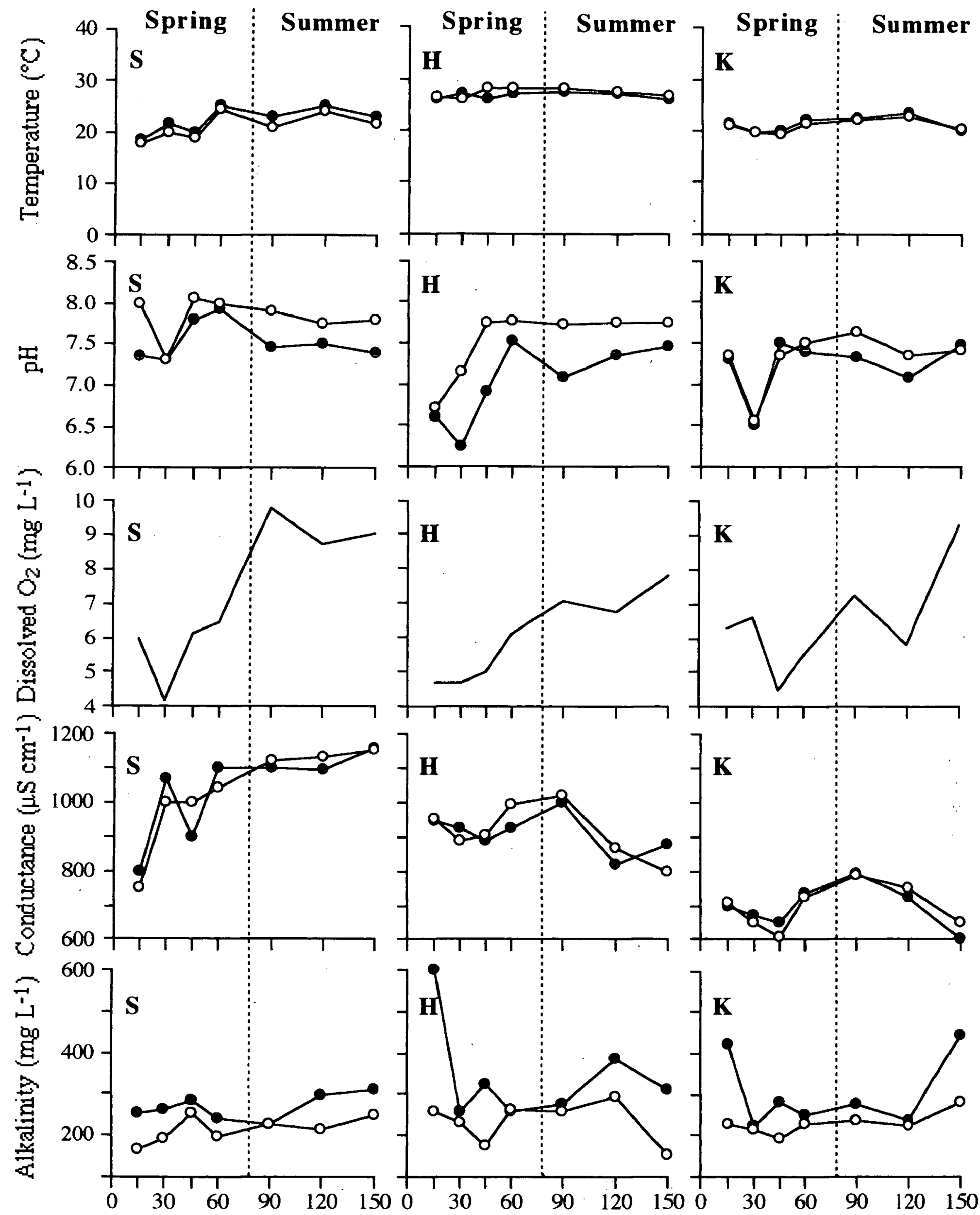

Days

Fig. 1. Composition of surface water (open dots) and water at the bottom of the cylinders (full dots) in the three stations (S : Sebou, $\mathrm{H}:$ Sidi Harazem, K : Ain Chkef). Day 0 was 28 March 1996. Each dot represents the mean of two values.

Fig. 1: Evolution des paramètres physico-chimiques de l'eau superficielle (points blancs) et de l'eau contenue dans les cylindres (points noirs) au niveau des trois stations d'étude (S : Sebou, H : Sidi Harazem, K : Aïn Chkef). Le jour 0 était le 28 mars 1996. Chaque point correspond à la moyenne de 2 mesures. 


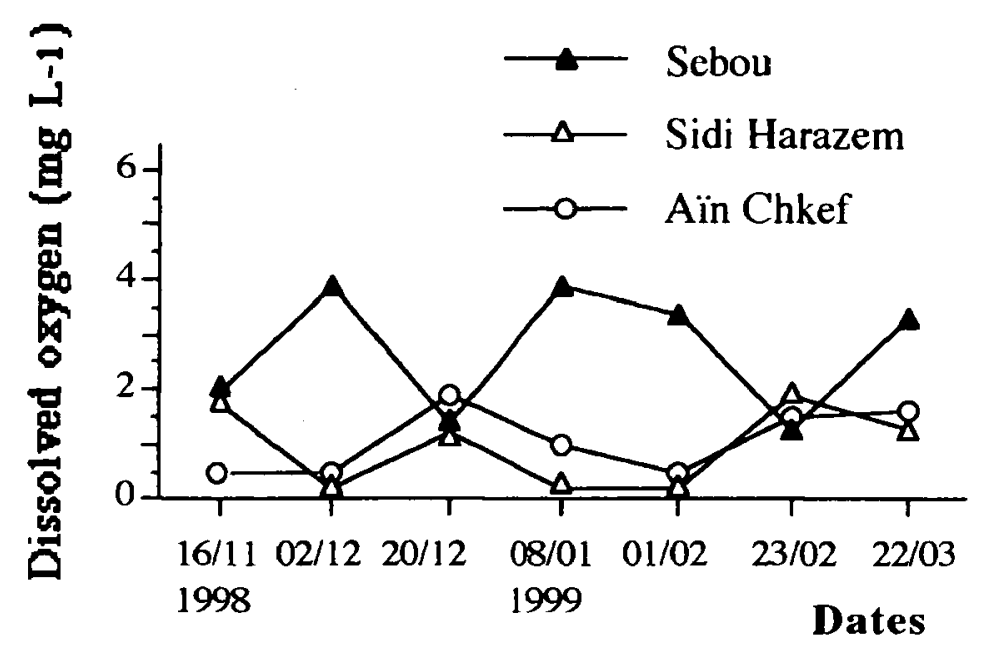

Fig. 2. Dissolved oxygen in the interstitial water of the three stations in 1998-99.

Fig. 2. Évolution de l'oxygène dissous de l'eau interstitielle au niveau des trois stations en 1998-99.

\subsection{Occurrence of Hyphomycetes}

We found no hyphomycete spore on the poplar leaves buried in the sediments of Ain Chkef. At the surface, at least three species were identified by both methods, on fresh and dried leaves: Tetracladium marchalianum and Anguillospora longissima (late February), Alatospora acuminata and Anguillospora longissima (early March), and Alatospora acuminata (second collection date in March).

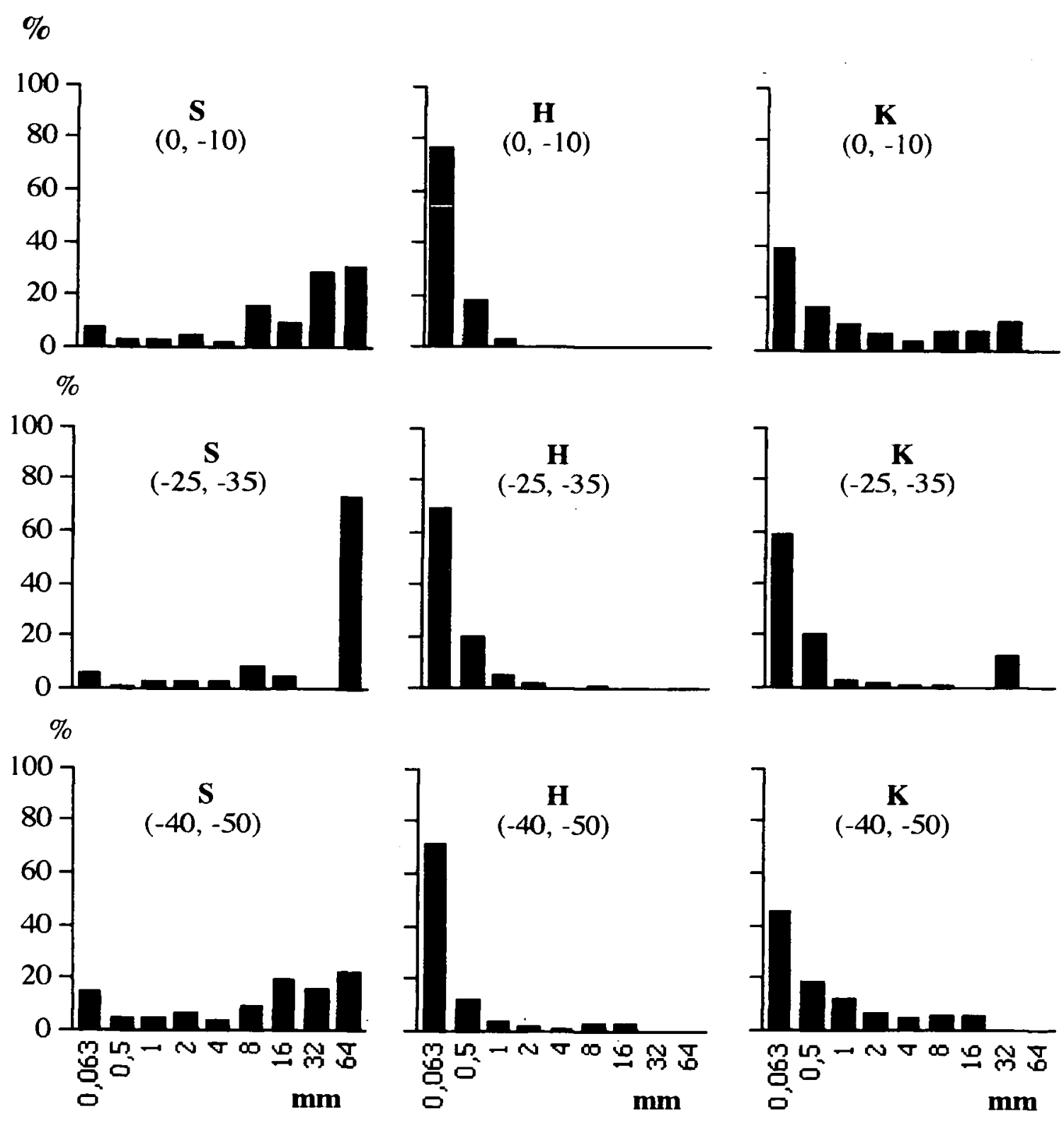

Fig. 3. Sediment grain size in each station (S : Sebou, H : Sidi Harazem, K : Ain Chkef) and each depth $(0,-10 \mathrm{~cm}) ;(-25,-35) ;(-40,-50)$, as percentages of total mass.

Fig. 3. Composition granulométrique des sédiments de chaque station ( $\mathrm{S}:$ Sebou, $\mathbf{H}:$ Sidi Harazem, $\mathrm{K}$ : Aïn Chkef) et pour chaque profondeur $(0,-10 \mathrm{~cm}) ;(-25,-35) ;(-40,-50)$. Les résultats de chaque classe dimensionnelle de particules sont exprimés en pourcentage de la masse totale de l'échantillon. 

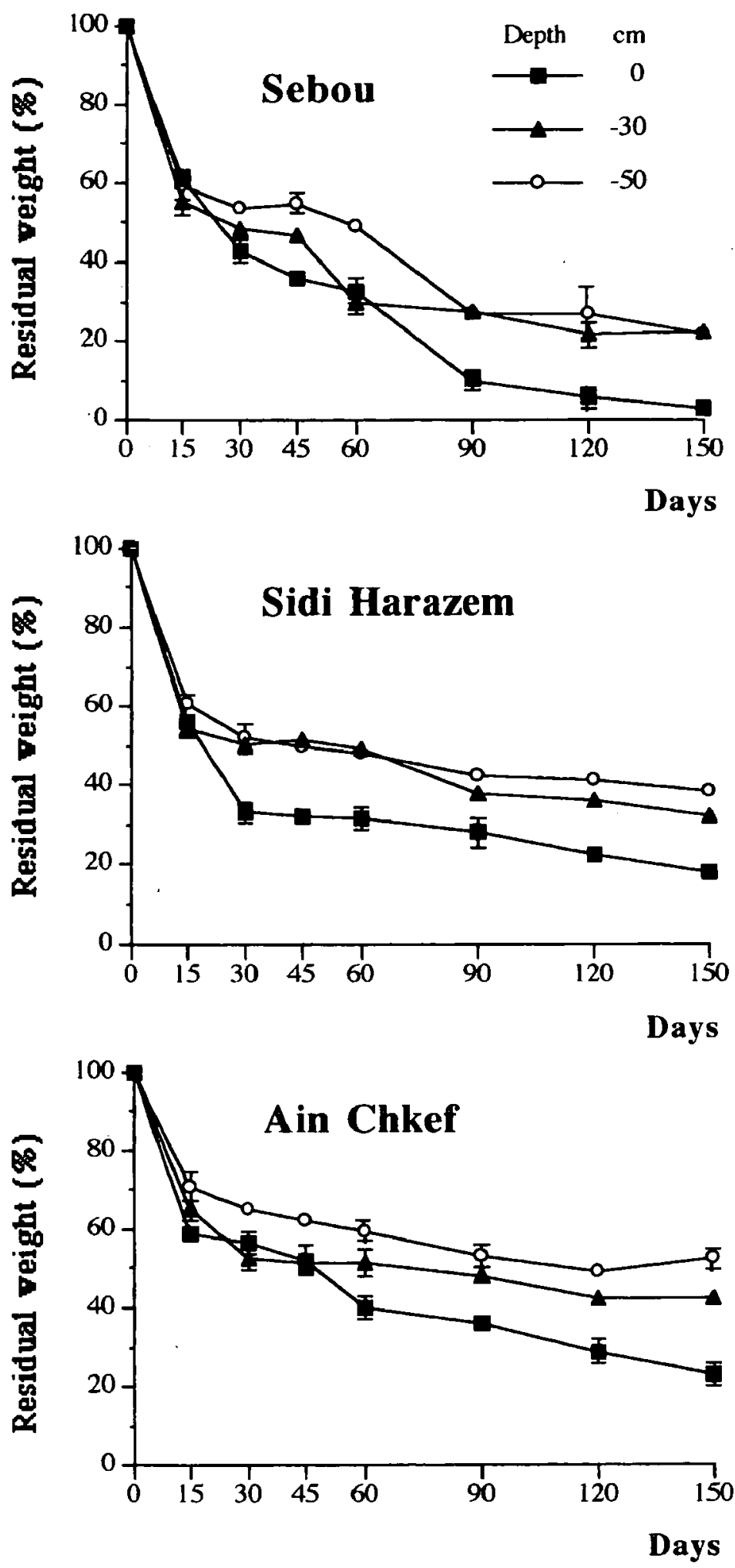

Fig. 4. Weight loss of poplar leaves at the three depths versus time. Day 0 was 28 March 1996. Each dot represents the mean of 6 leaf batches. Vertical bars show the standard deviation.

Fig. 4 - Variation du poids des feuilles du peuplier noir déposées dans les cours d'eau, en fonction de la profondeur et du temps. Le jour 0 était le 28 mars 1996. Chaque point représente la moyenne de six lots de feuilles. Les barres verticales représentent l'écart type.
Table 1. Exponential daily breakdown coefficients (k), correlation coefficients ( $r$ ) of the negative exponential model, and weight loss of the leaves of Populus nigra (P) and Quercus ilex (C) in the three stations, Sebou, Sidi Harazem and Ain Chkef. T $50:$ number of days after which the leaves lost $50 \%$ of their weight according to the exponential model. P 150 : actual weight loss at the end of the experiment (after 150 days). Also see Figs 4 and 5.

Tableau 1. Coefficients exponentiels de dégradation journalière, coefficients de corrélation du modèle exponentiel négatif et perte de poids des feuilles de Populus nigra (P) et Quercus ilex (C) au niveau des trois stations d'étude, Sebou, Sidi Harazem et Aïn Chkef. T $50:$ nombre de jours nécessaires pour que les feuilles perdent $50 \%$ de leur poids, d'après le modèle exponentiel. P 150 : Perte de poids effectivement mesurée à la fin de l'expérience ( 150 jours) (figures 4 et 5 ).

Sebou

\begin{tabular}{ccccccccc}
\hline & \multicolumn{2}{c}{$-\mathbf{k}$} & \multicolumn{2}{c}{$\mathbf{r}$} & \multicolumn{2}{c}{ T 50 } & $\mathbf{j})$ & \multicolumn{2}{c}{$\mathbf{P}$} & $\mathbf{1 5 0}$ & $(\%)$ \\
\cline { 2 - 9 } & $\mathbf{P}$ & $\mathbf{C}$ & $\mathbf{P}$ & $\mathbf{C}$ & $\mathbf{P}$ & $\mathbf{C}$ & $\mathbf{P}$ & $\mathbf{C}$ \\
\cline { 2 - 9 } Surface & 0,0240 & 0,0036 & 0,97 & 0,87 & 29 & 193 & 97 & 49 \\
$-30 \mathrm{~cm}$ & 0,0092 & 0,0024 & 0,91 & 0,81 & 75 & 289 & 78 & 38 \\
$-50 \mathrm{~cm}$ & 0,0093 & 0,0021 & 0,93 & 0,80 & 75 & 330 & 78 & 34 \\
\hline
\end{tabular}

Sidi Harazem

\begin{tabular}{|c|c|c|c|c|c|c|c|c|}
\hline & \multicolumn{2}{|c|}{$-\mathbf{k}$} & \multicolumn{2}{|c|}{$\mathbf{r}$} & \multicolumn{2}{|c|}{ T 50 (j) } & \multicolumn{2}{|c|}{ P $150(\%)$} \\
\hline & $\mathbf{P}$ & C & $\mathbf{P}$ & C & $\mathbf{P}$ & C & $\mathbf{P}$ & C \\
\hline Surface & 0,0089 & 0,0036 & 0,87 & 0,91 & 78 & 193 & 82 & 47 \\
\hline$-30 \mathrm{~cm}$ & 0,0059 & 0,0023 & 0,82 & 0,82 & 118 & 301 & 68 & 36 \\
\hline$-50 \mathrm{~cm}$ & 0,0048 & 0,0020 & 0,87 & 0,77 & 144 & 347 & 62 & 33 \\
\hline
\end{tabular}

Ain Chkef

\begin{tabular}{|c|c|c|c|c|c|c|c|}
\hline \multicolumn{2}{|c|}{$-k$} & \multicolumn{2}{|c|}{$\mathbf{r}$} & \multicolumn{2}{|c|}{ T $50(j)$} & \multicolumn{2}{|c|}{ P $150(\%)$} \\
\hline $\mathbf{P}$ & C & $\mathbf{P}$ & $\mathbf{C}$ & $\mathbf{P}$ & C & $\mathbf{P}$ & C \\
\hline 0,0084 & 0,0025 & 0,95 & 0,87 & 83 & 277 & 77 & 38 \\
\hline 0,0043 & 0,0018 & 0,79 & 0,66 & 161. & 385 & 58 & 29 \\
\hline 0,0037 & 0,0015 & 0,84 & 0,67 & 187 & 462 . & 48 & 25 \\
\hline
\end{tabular}



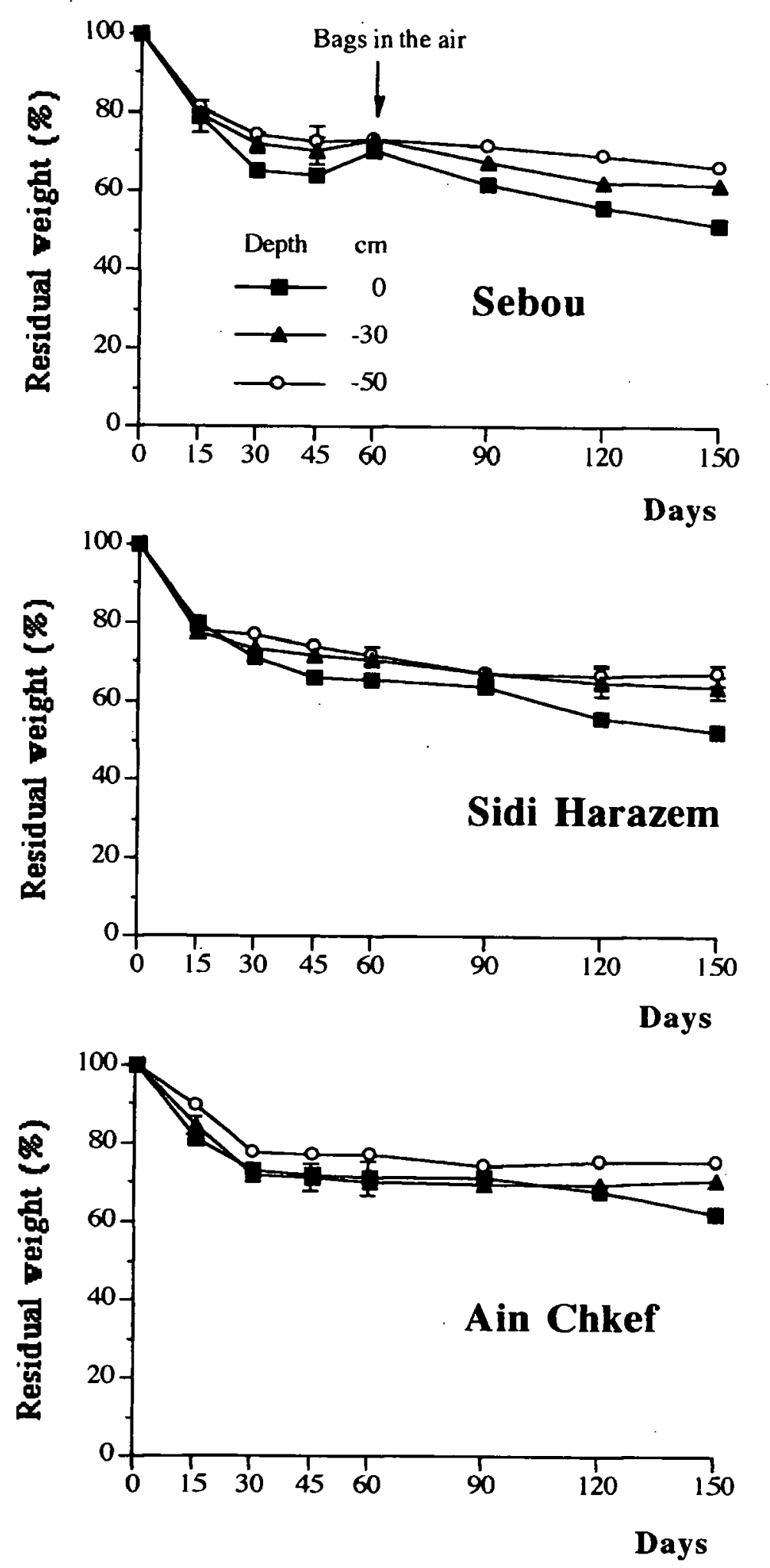

Fig 5. Weight loss of holm oak leaves at three depths versus time (S : Sebou, H : Sidi Harazem and K : Ain Chkef). Day 0 was 28 March 1996. Each dot represents the mean of 6 leaf batches. Vertical bars show the standard deviation.

Fig 5. Variation du poids des feuilles du chêne vert déposées dans les cours d'eau S : Sebou, $\mathrm{H}$ : Sidi Harazem et $\mathrm{K}$ : Aìn Chkef, en fonction de la profondeur et du temps. Le jour 0 était le 28 mars 1996. Chaque point représente la moyenne de six lots de feuilles. Les barres verticales représentent l'écart-type.
Table 2. Comparison of breakdown curves by ANCOVA. * means $\mathrm{p}$ $<0.05$, ns means non significant.

Tableau 2. Comparaison des courbes de dégradation par analyse de covariance. $* p<0,05 ; n s=$ différence non significative.

$\begin{array}{lcc}\begin{array}{l}\text { A Comparison between leaf species } \\ \text { Stations }\end{array} & \begin{array}{c}\text { Strata } \\ (0)\end{array} & \begin{array}{c}\text { Species } \\ \text { Sebou (S) }\end{array} \\ & (-30) & * \\ & (-50) & * \\ & (0) & * \\ \text { Sidi Harazem (H) } & (-30) & * \\ & (-50) & * \\ & & \\ \text { Ain Chkef (K) } & (0) & * \\ & (-30) & *\end{array}$

B/ Comparison between stations

(0)

$\mathrm{S}$ and $\mathrm{H}$

$S$ and $K$

$\mathrm{H}$ and $\mathrm{K}$

$S$ and $H$

$S$ and $K$

$\mathrm{H}$ and $\mathrm{K}$

$\mathrm{S}$ and $\mathrm{H}$

$S$ and $K$

$\mathrm{H}$ and $\mathrm{K}$

C/ Comparison between depths Strata Stations

(0) $(-30)$ Sebou Sidi Harazem Ain Chkef

\section{Poplar}

ns

ns

ns

Sebou

(-30) (-50) Sidi Harazem Ain Chkef

ns ns

ns

Sebou

(0) $(-50)$ 
Poplar
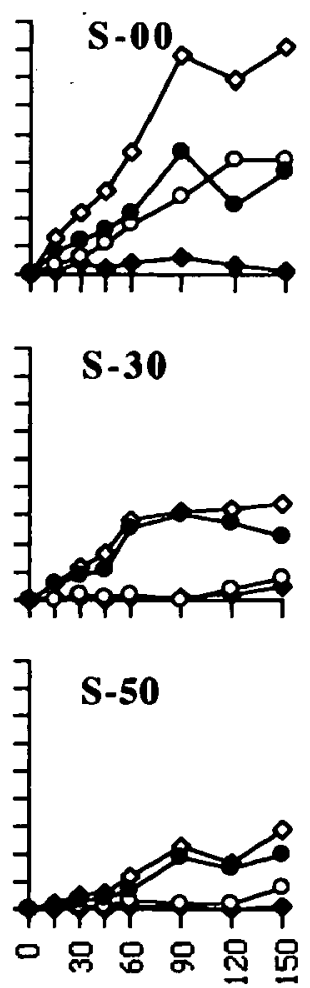

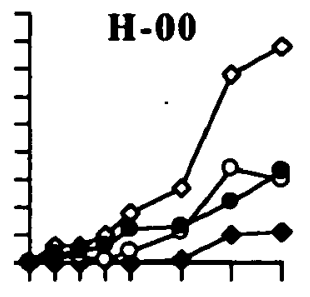

H-30
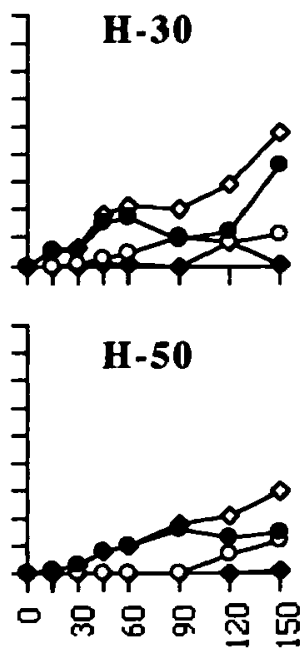
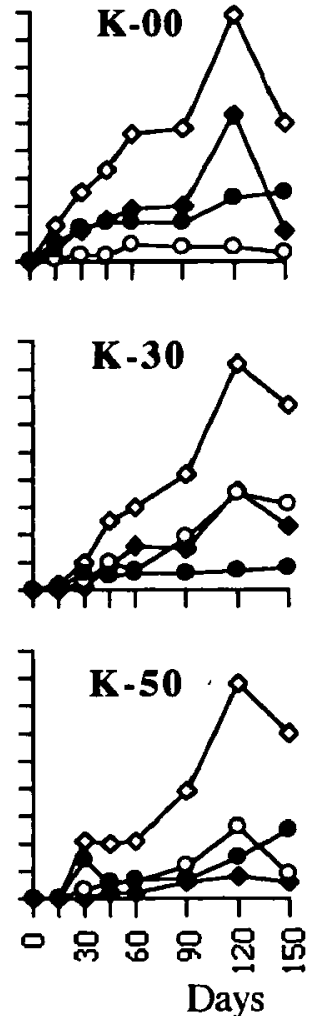

Holm oak
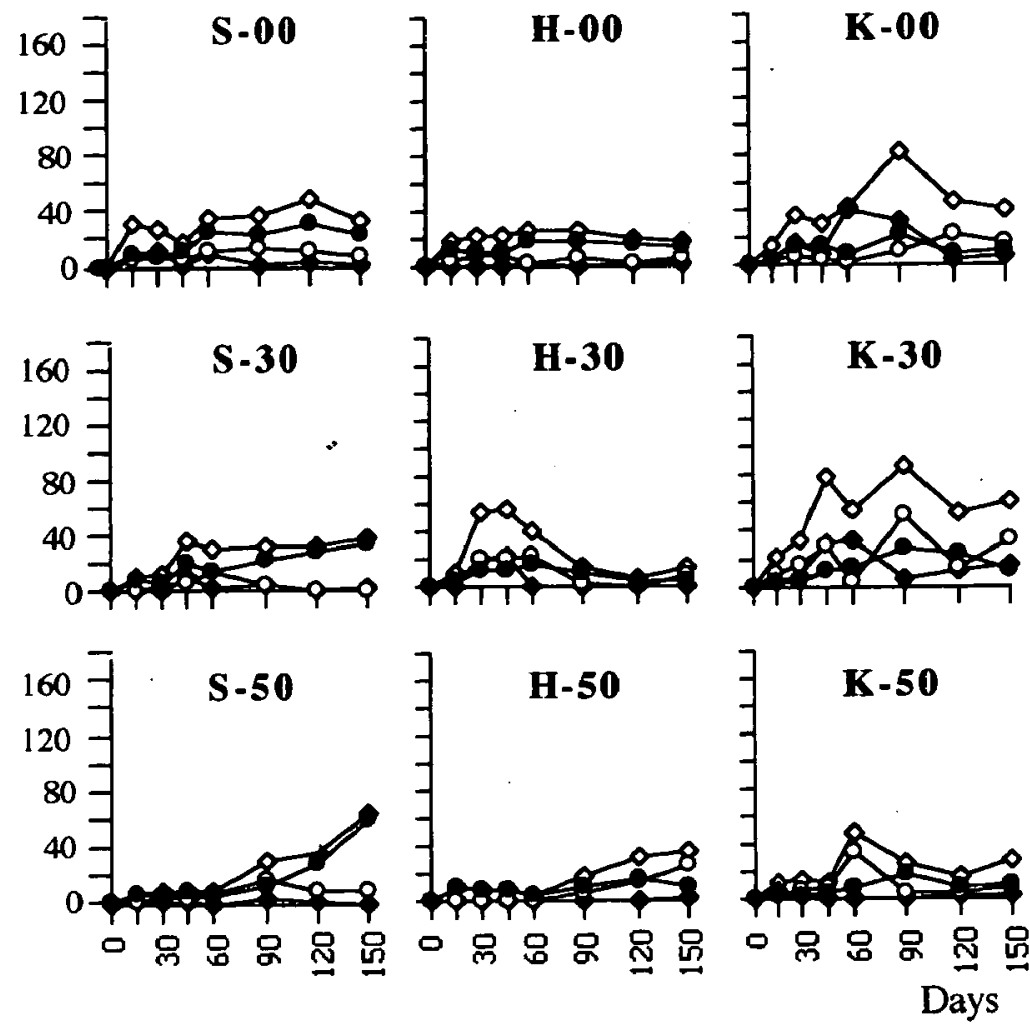
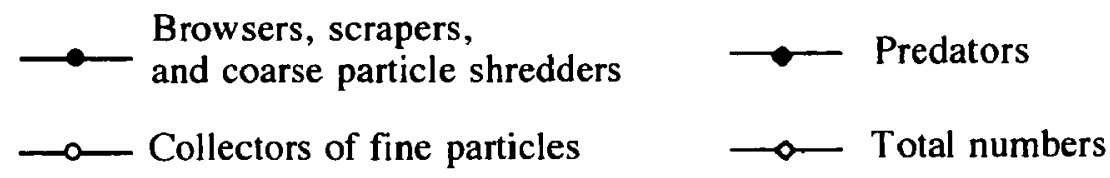

Fig. 6. Changes in numbers of invertebrates per gramme of residual litter according to leaf species, depth and station. Day 0 was $28 \mathrm{March}$ 1996.

Fig. 6. Évolution au cours du temps du nombre d'individus de différents groupes trophiques par gramme de feuilles restant dans chaque sachet selon l'espèce foliaire, les stations et la profondeur. Le jour 0 était le 28 mars 1996.

\section{Discussion}

Temperatures were in accordance with the origin of the water : despite small tributaries, Sidi Harazem was the warmest. It is difficult to draw a conclusion as to the origin of the water at the bottom of the open cylinders. This water was definitely not pure interstitial water but, considering the differences between some of the curves, it may have been a mixture of interstitial and surface water.

Late morning oxygen concentrations exceeding saturation as in Sebou and Ain Chkef in summer mean lack of equilibrium with the atmosphere and often oxygen deficit at the end of the night. The low levels in the sediment water of Sidi Harazem and Ain.Chkef collected by pumping indicate poor connection with surface water and the respiration of bacteria living on buried organic matter. In contrast, higher oxygen concentration and the presence of coarse particles (diameter 8-
$64 \mathrm{~mm}$ ) in the Sebou sediment are indicative of hyporheic water flow.

If leaf breakdown has been extensively investigated in temperate climates, little data is available at present for Mediterranean countries. Our paper describes the breakdown of leaves that reached the water and sediment under a dry state. This is what happens to dead leaves that have remained on the bushes or on the banks for a few days under the semi-arid climate of Northeastern Morocco. Stout et al. (1985) attributed the high biomass of aquatic invertebrates collected from fresh leaves to the attractive and highly nutritive quality of the leaves. However, Bärlocher $(1990,1991)$ stressed that dried leaves initially lose more weight than fresh ones in the water. According to Sridhar \& Bärlocher (1993), fresh leaves retain protective substances (tannins, polyphénols, pigments...) for long periods ; these substances repel invertebrates and thus reduce initial breakdown rates. However total duration 
Table 3. List of taxa collected in Oueds Sebou (S), Sidi Harazem (H), Ain Chkef (K) with indication of their trophic group according to Cummins \& Wilzbach (1985) and Tachet et al. (1996). The stars show the abundance of the taxa in the samples $\left(*\right.$ rare, ${ }^{* *}$ medium, and ${ }^{* * *}$ abundant).

Tableau 3. Inventaire des taxons récoltés dans les Oueds Sebou (S), Sidi Harazem (H), Aïn Chkef (K) et leur classification par groupes trophiques selon Cummins \& Wilzbach (1985) et Tachet et al. (1996) (les signes * à *** indiquent la fréquence de présence dans les relevés, * faible, ** moyenne, *** élevée).

\begin{tabular}{|c|c|c|c|c|c|c|c|c|c|}
\hline Taxon & $\mathbf{S}$ & $\mathbf{H}$ & $\mathbf{K}$ & Trophic Group & Taxon & $\mathbf{S}$ & $\mathbf{H}$ & $\mathbf{K}$ & Trophic Group \\
\hline $\begin{array}{l}\text { PLATYHELMINTHES } \\
\text { Turbellaria }\end{array}$ & & & & & $\begin{array}{l}\text { ARTHROPODA } \\
\text { CRUSTACEA }\end{array}$ & & & & \\
\hline Dugesia gonocephala & $*$ & * & *** & Predator & Atyaephyra sp. & $* *$ & $*$ & & Shredder \\
\hline ASCHELMINTHES & & & & & INSECTA & & & & \\
\hline Nematoda & * & * & * & Other & Ephemeroptera & & & & \\
\hline & & & & & Caenis sp. & ** & $* *$ & $*$ & Collector \\
\hline ANNELIDA & & & & & Heptagenia sp. & $*$ & $*$ & & Scraper \\
\hline Oligochaeta & & & & & & & & & \\
\hline Lumbricus sp. & $*$ & * & $*$ & Collector & Odonata & & & & \\
\hline Tubificidae & $* *$ & ** & *** & Collector & Libellulidae & & * & $* * *$ & Predator \\
\hline Naididae & $* * *$ & $* * *$ & $* * *$ & Collector & Gomphidae & & $*$ & & Predator \\
\hline Achaeta & & & & & Heteroptera & & & & \\
\hline Glossiphonia & & & $* * *$ & Predator & Nepa sp. & & & * & Predator \\
\hline Helobdella & & * & $* * *$ & Predator & & & & & \\
\hline Erpobdella & & & $*$ & Predator & $\begin{array}{l}\text { Megaloptera } \\
\text { Sialis sp. }\end{array}$ & $*$ & * & ** & Predator \\
\hline MOLLUSCA & & & & & & & & & \\
\hline Gastropoda & & & & & Coleoptera & & & & \\
\hline Melanopsis praemorsa & & $* * *$ & ** & Shredding scraper & Dytiscidae & $*$ & * & * & Predator \\
\hline Melanopsis costella & $* * *$ & & ** & Shredding scraper & & & & & \\
\hline Physa acuta & & ** & $* * *$ & Shredding scraper & Trichoptera & & & & \\
\hline Lymnea truncatula & & $*$ & $* *$ & Scraper & Hydropsychidae & * & * & * & Filterer \\
\hline Planorbis sp. & & * & ** & Browsing scraper & & & & & \\
\hline Ancylus fluviatilis & & & $*$ & Scraper & Diptera & & & & \\
\hline Valvata sp. & & ** & * & Scraper & Culicidae & $*$ & * & $*$ & Filterer \\
\hline Succinea putris & & & $*$ & Scraper & Simuliidae & $*$ & $*$ & & Filterer \\
\hline & & & & & Chironomidae & ** & ** & $* * *$ & Collector-Filterer \\
\hline Bivalvia & & & & & Ceratopogonidae & $*$ & ** & $*$ & Shredder \\
\hline Pisidium & * & $*$ & $* *$ & Filterer & & & & & \\
\hline \multicolumn{10}{|c|}{ Taxonomic richness 17} \\
\hline
\end{tabular}

of breakdown was often found to be identical for both categories (Gessner 1991, Chergui \& Pattee 1993).

The negative exponential model seems to describe buried leaf breakdown with acceptable correlation. However $50 \%$ breakdown evaluated according to this model was overestimated, at least for poplar leaves: in Sidi Harazem values calculated in Table 1 from the model were 78,118 , and 144 days at depths of $0,-30$, and $-50 \mathrm{~cm}$, respectively, whereas actual values read from Fig. 4 are 21, 30, and 45 days. In this site, initial weight loss was especially fast and was followed by slower breakdown after day 30 .

One of the most evident results of the present study is the lower breakdown rate of $Q$. ilex leaves. This may be clearly related with leaf texture and chemical composition. Holm oak leaves have a sclerified cuticle that protects them from leaching and attack by micro-organisms and invertebrates; according to Gessner \& 
Chauvet (1994) they contain much tannin $(6.7 \%)$ and lignin $(18.5 \%)$ and little phosphorus $(0.047 \% \mathrm{P}$ and $1.6 \%$ N). Chergui \& Pattee (1990) found $0.087 \% \mathrm{P}$ and $0.89 \% \mathrm{~N}$ in poplar leaves.

The scanty data from the literature on Mediterranean holm oak makes comparisons difficult. Gessner \& Chauvet (1994) measured a daily breakdown rate of $k$ $=0.0042$ at the surface of the sediment of a mountain stream in the French Pyrenees mountains. Despite climate differences in temperature (between 3.3 and $12.0^{\circ} \mathrm{C}$ in the Pyrenees and between 18 and $29^{\circ} \mathrm{C}$ in Morocco) rate was higher in France than in Morocco where $\mathrm{k}=0.0025-0.0036$. Owing to the $5 \%$ gradient in France, current velocity and/or oxygen availability were presumably greater there than in Morocco. Chergui $\&$ Pattee (1991a) also noted that the influence on breakdown rate of microhabitat within the same district dominated over the influence of climate differences between France and Morocco.

Breakdown rates of holm oak leaves on the soil of southwestern French forests measured by Poinsot-Balaguer \& Livrelli (1994) and Poinsot-Balaguer (1996) were between 0.00033 and 0.00075 per day, according to season and microclimate. In a vineyard landscape in the same region, Orgeas et al. (1998) found values of 0.0004-0.0020. These values are lower than all those from the Moroccan sites except for the leaves buried in the sediment at Ain Chkef ( $\mathrm{k}=0.0018$ and 0.0015$)$. Faster breakdown in aerated water than in the air is well documented (Rice 1974, Herbst 1980, Rounick \& Winterbourn 1983, Cummins et al. 1984, Pattee et al. 1986) and easy to explain by the need of microorganisms for water. But here we see that breakdown in stream sediments is also most often faster than on dry or damp soil despite the presumable absence of hyphomycetes.

Breakdown coefficients measured here for poplar leaves at the surface of the sediments were 0.0084 and 0.0089 at Ain Chkef and Sidi Harazem, but 0.0240 in the Sebou. Gasith \& Lucy (1976) measured a lower rate of 0.0057 for poplar leaves in the littoral zone of a eutrophic lake, which may be explained by the standing water in the lake. At the surface of the sediment in a lowland $\left(<30{\mathrm{~cm} . \mathrm{s}^{-}}^{1}\right)$ forest stream, Herbst (1980) also found a breakdown rate of 0.006 . The rates in a small pond were 0.006 in autumn, 0.008 in winter and in spring, and 0.011 in summer (Chergui \& Pattee 1990). In Morocco, breakdown was faster in Oued Sebou which also had the fastest current velocity.

Buried poplar leaves also decayed faster in Morocco $(\mathrm{k}=0.0037-0.0093)$ than in Wisconsin, U.S.A., as des- cribed by Herbst (1980) $(\mathrm{k}=0.002)$. Here differences in breakdown rates are in accordance with differences in mean temperature.

The sites can be ranked Sebou - Sidi Harazem - Ain Chkef according to breakdown rates. The curves in Figs 4 and 5 show greatest weight loss between days zero and 15. This loss includes all initial processes, including leaching. Nykvist (1963) showed that leaching was influenced by temperature. The water was consistently warmer and initial weight loss also seemed greater at Sidi Harazem than at Ain Chkef. Further differences between thëse two sites can be explained by the influence of temperature on biological processes. But, as both breakdown rate and current velocity were fastest in Oued Sebou, water flow seems to have predominated over temperature. This occurred, not only at the surface, but within the sediments, as noted above.

The abundance and shredding efficiency of the fauna also influence leaf breakdown. The prosobranch gastropod Melanopsis, whose impact has been extensively demonstrated by Chergui \& Pattee (1991a, 1991b, 1992), was dominant in the Sebou where it was present even in the deeper sediment strata. Thus faster breakdown in this site may be explained simultaneously by greater current velocity, coarser substratum, and their consequences: interstitial water flow, higher oxygen concentration, and the presence of shredders at all depths.

The final decrease in invertebrate numbers per leaf mass was presumably due to the gradual disappearance of readily consumable substances.

In all three sites, the leaves incubated at the surface of the sediments decayed faster than those that were buried. Several explanations may be given.

Essafi et al. (1994) found that, in fastly-flowing water, leaves incubated at the surface of the sediment also decayed faster than buried leaves. In slowly-flowing water they found no difference between these two categories. Presumably physical abrasion only occurred at the surface in the fastly-flowing water. This must have been the case at the surface of the sediments in Oued Sebou and explains why breakdown rate there $(\mathrm{k}=0.0240)$ was so much higher than in all other locations $(\mathrm{k}=0.0037-0.0093)$, whether at the other sites or in the sediment of the Sebou itself.

Dissolved oxygen concentrations were always higher in the open than in the interstitial water (but remember that two years separated the terms of this comparison). Even in Oued Sebou, concentration in the open water was above $4 \mathrm{mg} \cdot \mathrm{L}^{-1}$ and concentration 
in the interstitial water was below this level. Differences were much greater in the other two stations, where oxygen in the interstitial water was below 2 $\mathrm{mg} . \mathrm{L}^{-1}$ and sometimes zero. This is a second explanation for slower breakdown.

A third explanation is the weight of the sediment that pressed the leaves together and left less surface for attack by microorganisms and invertebrates than at the surface.

Moreover no hyphomycete conidia were found in the sediments of Ain Chkef and leaf conditioning was presumably only due to bacteria. According to Bärlocher \& Kendrick (1973) and Suberkropp \& Klug (1976), the nutritive value of plant litter is low as long as it is not conditioned by hyphomycetes. Leaves conditioned at the surface must have been more attractive for invertebrates and hence were more quickly shredded. Herbst (1980) agreed with these observations: shredders preferred the poplar and maple leaves incubated at the surface over those incubated 10 or 15 $\mathrm{cm}$ within the sediment.

Mayack et al. (1989) observed that leaves buried in the sediment decayed faster during the warm season, that shredders were rare in the sediment in winter but that they migrated downwards in spring. This relationship between shredders and leaf breakdown has been stressed by many authors (Petersen \& Cummins 1974, Bärlocher \& Kendrick 1974, Hart \& Howmiller 1975, Sedell et al. 1975) for leaves exposed at the surface of the sediment but not for buried leaves. For buried leaves, Essafi et al. (1994) found no significant relationship and they concluded that the leaf bags were only used by the invertebrates as a substratum.

Indeed, leaf packs may be used by invertebrates and the shredders among them, both as a habitat and as a source of food (Dobson \& Hildrew 1992). Richardson (1992) believed that food and not refuge was the primary value of leaf packs for invertebrates. Rounick \& Winterbourn (1983) measured generally lower microbial respiration and leaf nutritive value when the leaves were buried in the sediment. In contrast, Herbst (1980) found no difference in microbial protein content between leaves incubated at and below the surface.

In the present investigations, breakdown rates and invertebrate and shredder numbers were distinctly greater for poplar than for holm oak leaves. But for each species no relationship appeared between these data, both among sites and among depths, and the role of invertebrates in the breakdown of buried leaves remains uncertain.

\section{Conclusion}

These results stress the importance of water flow (in the Sebou), temperature (at Sidi Harazem and Ain Chkef) and leaf composition under the Mediterranean climate. It shows the absence of hyphomycete sporulation and possibly fungal growth in the sediment of one of the sites, but the penetration of epigean shredders as far down as $-50 \mathrm{~cm}$. Leaf breakdown was slower but not negligible in the hyporheic zone of the three sites. This suggests that leaf conditioning may have been only due to bacteria, which needs confirmation.

\section{References}

Bärlocher F. 1990. - Factors that delay colonization of fresh alder leaves by aquatic hyphomycetes. Arch. Hydrobiol., $119: 249-255$.

Bärlocher F. 1991. - Fungal colonization of fresh and dry alder leaves in the River Teign. Nova Hedwigia, 52 : 349-357.

Bärlocher F. \& Kendrick B. 1973. - Fungi and food preference of Gammarus pseudolimnaeus. Arch. Hydrobiol., 72 : 501-516.

Bärlocher F. \& Kendrick B. 1974. - Dynamics of the fungal population on leaves in a stream. J. Ecol., $62: 761-791$.

Bou C. \& Rouch R. 1967. - Un nouveau champ de recherches sur la faune aquatique souterraine. C.R. Acad. Sci. Paris, 265 : 369-370.

Boulton A.J. \& Foster J.G. 1998. - Effects of buried leaf litter and vertical hydrologic exchange on hyporheic water chemistry and fauna in a gravel-bed river in northern New South Wales, Australia. Freshwat. Biol., $40: 229-243$.

Chergui H. \& Pattee E. 1988. - The effect of water current on the decomposition of dead leaves and needles. Verh. Internat. Verein. Limnol., 23 : 1294-1298.

Chergui H. \& Pattee E. 1990. - The influence of season on the breakdown of submerged leaves. Arch. Hydrobiol., $120: 1-12$.

Chergui H. \& Pattee E. 1991a. - Dégradation des feuilles mortes allochtones dans le réseau de la basse Moulouya, au Maroc. Acta acologica, $12: 543-560$.

Chergui H. \& Pattee E. 1991b.- An experimental study of the breakdown of submerged leaves by hyphomycetes and invertebrates in Morocco. Freshwat. Biol., 26 : 97-110.

Chergui H. \& Pattee E. 1992. - Processing of fresh and dry Salix leaves in a Moroccan river system. Acta acologica, 13 (3) : 291-298.

Chergui H. \& Pattee E. 1993.- Fungal and invertebrate colonization of Salix fresh and dry leaves in a Moroccan river system. Arch. Hydrobiol., 127 : 57-72.

Cummins K.W. 1974. - Structure and function of stream ecosystems. BioScience, 24 : 631-641.

Cummins K.W., Petersen R.C., Howard F.O., Wuycheck J.C. \& Holt V.I. 1973. - The utilisation of leaf litter by stream detritivores. Ecology, 54 : 336-345.

Cummins K.W., Minshall G.W., Sedell J.R., Cushing C.E. \& Petersen R.C. 1984. - Stream ecosystem theory. Verh. Internat. Verein. Limnol., 22 : 1818-1827.

Cummins K.W. \& Wilzbach A.M. 1985. - Field procedures for analysis of functional feeding groups of stream invertebrates. Ap palachian Environmental Laboratory, University of Maryland, Frostburg. Cont. $\mathrm{N}^{\circ} 1611: 18 \mathrm{p}$.

Dobson M. \& Hildrew A.G. 1992. - A test of resource limitation among shredding detritivores in low order streams in southern England. J. Anim. Ecol., 61 : 69-77. 
Essafi K., Chergui H., Pattee E. \& Mathieu J. 1994. - The breakdown of dead leaves buried in the sediment of a permanent stream in Morocco. Arch. Hydrobiol., 130 (1) : 105-112.

Fisher S.G. \& Likens G.E. 1973. - Energy flow in Bear Brook, New Hampshire: an integrative approach to stream ecosystem metabolism. Ecol. Monogr., 43 : 421-439.

Gasith A. \& Lawacz W. 1976. - Breakdown of leaf litter in the littoral zone of a eutrophic lake. Ekol. Pol., 24 : 421-430.

Gessner M. 1991 .- Differences in processing dynamics of fresh and dried leaf litter in a stream ecosystem. Freshwat. Biol., 26 : 387-398.

Gessner M.O. \& Chauvet E. 1994. — Importance of stream microfungi in controlling breakdown rates of leaf litter. Ecology, 75 : $1807-1817$.

Gibert J. 1986. - Ecologie d'un système karstique jurassien. Hydrogéologie, dérive animale, transit de matières, dynamique de la population de Niphargus (Crustacé Amphipode). Thèse Univ. Lyon-I, Mém. Biospéol., Moulis, XIII (40), 380p.

Hart S.D. \& Howmiller R.P. 1975. - Studies on the decomposition of allochthonous detritus in two Southem California streams. Verh. Internat. Verein. Limnol., $19: 1665-1674$.

Herbst G.N. 1980. - Effects of burial on food value and consumption of leaf detritus by aquatic invertebrates in a lowland forest stream. Oikos, 35 : 411-424.

Kaushik N.K. \& Hynes H.B.N. 1971. - The fate of the dead leaves that fall into streams. Arch. Hydrobiol., $68: 465-515$.

Leichtfried M. 1985. - Organic matter in gravel streams (Project Ritrodat-Lunz). Verh. Internat. Verein. Limnol., 22 : 2058-2062.

Mayack D.T., Thorp J.H. \& Cothran M. 1989. - Effects of burial and floodplain retention on stream processing of allochtonous litter. Oikos, $54: 378-388$.

Nykvist N. 1963. - Leaching and decomposition of water-soluble organic substances from different types of leaf and needle litter. Studia forestalia suecica, $3: 1-31$.

Orgeas J., Ballini C. \& Poinsot-Balaguer N. 1998. - Dynamics of holm oak (Quercus ilex L.) litter decomposition in isolated habitats, in grape-growing ecosystems. Ecologie, 29 (3) : 459-466.

Pattee E., Bornard C. \& Mourelatos S. 1986. - La décomposition des feuilles mortes dans le réseau fluvial du Rhône : influence du milieu et principaux agents responsables. Sci. Eau, $5:$ 45-74.
Petersen R.C. \& Cummins K.W. 1974. - Leaf processing in a woodland stream. Freshwat. Biol., 4 : 343-368.

Poinsot-Balaguer N. 1996. - Effect of undergrowth-clearing on evergreen leaf litter decomposition and colonization by microarthropods. Pedobiologia, $40: 289-301$.

Poinsot-Balaguer N. \& Livrelli J.N. 1994. - Effects of forest undergrowth clearing on the decomposition of leaf litter and on the nutrient evolution in the leaves of evergreen oak in Mediterranean forest ecosystems (Porquerolles Islands, Provence - France). In : Bellan D. \& Bonin G. (Eds), Functioning and Dynamics of Natural and Perturbed Ecosystems. Sixth European Congress of Ecology, Marseille - France : 342 p.

Reice S.R. 1974. - Environmental patchiness and the breakdown of leaf litter in a woodland stream. Ecol., $55: 1271-1282$.

Richardson J.S. 1992. - Food, microhabitat, or both ? Macro-invertebrate use of leaf accumulations in a montane stream. Freshwat. Biol., 27 : 169-176.

Rodier J. 1975. - L'analyse de l'eau : eaux naturelles, eaux résiduaires, eaux de mer. Dunod (6ème édition) Paris : $629 \mathrm{p}$.

Rounick J.S. \& Winterbourn M.J. 1983. - Leaf processing in two contrasting beech forest streams: Effects of physical and biotic factors on litter breakdown. Arch. Hydrobiol., 96: 448-474.

Sedell J.R., Triska F.J. \& Triska N.S. 1975. - The processing of conifer and hardwood leaves in two coniferous forest streams. I. Weight loss and associated invertebrates. Verh. Internat. Verein. Limnol., 19 : 1617-1627.

Sridhar K.R. \& Bärlocher F. 1993. - Seasonal changes in microbial colonization of fresh and dried leaves. Arch. Hydrobiol., 128 (1): $1-12$.

Stout R.J., Taft W.T. \& Merritt R.W. 1985. - Patterns of macroinvertebrate colonization on fresh and senescent alder leaves in two Michigan streams. Freshwat. Biol., 15 : 573-579.

Suberkropp K. \& Klug M.J. 1976. - Fungi and bacteria associated with leaves during processing in a woodland stream. Ecology, 57 : 707-719.

Suberkropp K., Klug M.J. \& Cummins K.W. 1975. - Community processing of leaf litter in woodland streams. Verh. Internat. Verein. Limnol., 19 : 1653-1658.

Tachet H., Bournaud M. \& Richoux P. 1996. —Introduction à l'étude des macroinvertébrés des eaux courantes. Assoc. Fr. Limnol. et Univ. Lyon-I : $156 \mathrm{p}$. 